\title{
DOES PROTEIN SUPPLEMENTATION AND EXERCISE INTERFERE WITH RENAL FUNCTION AND STRUCTURE?
}

\author{
ASUPLEMENTAÇÃO DE PROTEÍNA E O EXERCICIO INTERFEREM NA FUNÇÃO EESTRUTURA RENAL?
}

Original Article

¿LA SUPLEMENTACIÓN DE PROTEÍNAS Y EL EJERCICIO INTERFIEREN EN LA FUNCIÓN Y ESTRUCTURA RENAL?

ARTIGO ORIGINAL

Artículo Original

Thiago Pontini de Assis ${ }^{1}$ (ID (Physician)

Caroline Simões Gonçalves ${ }^{1}$ (iD (Physician)

Maria Luísa Nonato Giannetto' (DD (Physician)

Carla Patrícia Carlos

(Biologist)

Patrícia Maluf Cury ${ }^{3}$ (DD

(Physician)

Heloisa Cristina Caldas ${ }^{4}$ (ID (Biologist)

Glória Elisa Florido Mendes4 (iD (Biomedical)

1. Faculdade CERES (FACERES), Medicine Course, São José do Rio Preto, SP, Brazil.

2. Faculdade CERES (FACERES), Discipline of Morphofunctional, Medicine Course, São José do Rio Preto, SP, Brazil.

3. Faculdade CERES (FACERES), Medicine Course Coordinator, São José do Rio Preto, SP, Brazil. 4. Faculdade de Medicina de São José do Rio Preto (FAMERP), LITEX Laboratory (Immunology and Experimental Transplants), São José do Rio Preto, SP, Brazil.

\section{Correspondence:}

Thiago Pontini de Assis. Rua Américo Brasiliense, 1025. São Paulo, SP, Brazil. 04715003. thiagopontini@gmail.com

\section{ABSTRACT}

Introduction: During physical activity, the body diverts blood to essential areas such as skeletal muscle, reducing the supply to non-essential areas such as the kidney. Whey protein is one of the most widely used supplements in gyms. Objectives: To evaluate renal function and renal structure in rats submitted to physical exercise with and without the use of protein supplementation. Methods: The protein used was Whey Hydro PRO 2 - Probiotica ${ }^{\oplus}$. It was administered orally (by gavage), diluted in mineral water $(1.8 \mathrm{~g} / \mathrm{kg}$ of body weight, shortly after swimming training). The rats were divided into four groups: rats with exercise (Exc), rats without exercise (ñExc), rats with exercise and with protein supplementation (Prot/Exc) and rats without exercise and with protein supplementation (Prot/ñExc). The training consisted of swimming for 30 minutes, using load equivalent to $2 \%$ of body weight, five times a week for a total of 10 weeks. The protein was administered by gavage, once daily, immediately after the training. Results: A reduced glomerular filtration rate was observed in the animals of the Exc group compared to those of the Prot/Exc group. Plasma creatinine values were similar between the groups submitted to exercise and those not submitted to exercise. Plasma sodium and the sodium excretion fraction were lower in the Prot/Exc group compared to the Exc group. Urinary excretion was similar between groups. Histological analysis: Significant hydropic degeneration was observed in the animals that received protein supplementation and submitted to exercise. Conclusion: These results show that exercise associated with protein supplementation $(2 \mathrm{~g} / \mathrm{day} / \mathrm{kg}$ ) leads to changes in the tubular mechanisms of sodium adjustments and structural changes in the renal parenchyma. Level of evidence Il; Therapeutic studies - Investigation the results of treatment.

Keywords: Kidney function tests; Dietary supplements; Whey proteins.

\section{RESUMO}

Introdução: Durante a atividade física o corpo faz remanejamento sanguíneo para áreas essenciais como a musculatura esquelética, reduzindo o suprimento em áreas não essenciais como o rim. O whey protein (proteína do soro do leite) é um dos suplementos mais usados nas academias. Objetivos: Avaliar a função e a estrutura renal em ratos submetidos ao exercício físico sem e com o uso da suplementação de proteina. Métodos: A proteína usada foi Whey Hydro PRO 2 - Probiótica ${ }^{\oplus}$, sendo administrada por via oral (gavagem), diluída em água mineral (1,8 g/kg de peso corporal logo após o treino de natação). Os ratos foram divididos em quatro grupos: ratos com exercício (Exc), ratos sem exercício (ñExc), ratos com exercício e com suplementação alimentar de proteína (Prot/Exc) e ratos sem exercício e com suplementação alimentar de proteína (Prot/ñExc). O treinamento consistia em natação por 30 minutos, com utilização de carga, equivalente a $2 \%$ do peso corporal, 5 vezes por semana em um total de 10 semanas. A proteína foi administrada por gavagem, uma vez ao dia e logo depois do treino. Resultados: Observou-se queda da filtração glomerular renal nos animais do grupo Exc vs. Prot/Exc. Os valores de creatinina plasmática foram semelhantes entre os grupos que praticaram o exercício vs. os que não praticaram. Para o sódio plasmático e a fração de excreção de sódio, os valores foram menores no grupo Prot/Exc quando comparados com o grupo Exc. A excreção urinária de ureia foi semelhante entre os grupos. Análise histológica: Observou-se degeneração hidrópica significativa nos animais que receberam a suplementação de proteína e realizaram o exercício. Conclusão: Esses resultados mostram que o exercício em conjunto com a suplementação de proteína (2 g/dia/ $/ \mathrm{gg}$ ), determina alterações nos mecanismos tubulares de ajustes do sódio e alterações estruturais no parênquima renal. Nível de evidência Il; Estudos terapêuticos - Investigação dos resultados do tratamento.

Descritores: Testes de função renal; Suplementação nutricional; Proteínas do soro do leite.

\section{RESUMEN}

Introducción: Durante la actividad física el cuerpo hace reubicación sanguínea hacia áreas esenciales como la musculatura esquelética, reduciendo el suministro en áreas no esenciales como el riñón. La whey protein (proteína del suero de la leche) es uno de los suplementos más usados en los gimnasios. Objetivos: Evaluar la función y la estructura renal en ratones sometidos al ejercicio físico sin y con el uso de la suplementación de proteína. Métodos: La proteína utilizada fue Whey Hydro PRO 2-Probiótica ${ }^{\oplus}$ siendo administrada vía oral (gavaje), diluida en agua mineral (1,8 g/kg de peso corporal luego después del entrenamiento de natación). Los ratones fueron divididos en cuatro grupos: ratones con ejercicio (Exc), ratones sin ejercicio (ñExc), ratones con ejercicio y con suplementación alimentaria de proteína (Prot/Exc) 
y ratones sin ejercicio y con suplementación alimenticia de proteína (Prot/ñExc). El entrenamiento consistía en natación por 30 minutos, con uso de carga, equivalente al $2 \%$ del peso corporal, 5 veces por semana en un total de 10 semanas. La proteína fue administrada por gavaje, una vez al dia y luego después del entrenamiento. Resultados: Se observó caída de la filtración glomerular renal en los animales del grupo Exc vs Prot/Exc. Los valores de creatinina plasmática fueron semejantes entre los grupos que practicaron el ejercicio vs los no practicaron. Para el sodio plasmático y la fracción de excreción de sodio, los valores fueron menores en el grupo Prot/Exc cuando comparados con el Exc. La excreción urinaria de urea fue semejante entre los grupos. Análisis histológico: Se observó degeneración hidrópica significativa en los animales que recibieron la suplementación de proteínas y realizaron el ejercicio. Conclusión: Estos resultados muestran que el ejercicio en conjunto con la suplementación de proteína (2 g/día/ $\mathrm{Kg}$ ), determina alteraciones en los mecanismos tubulares de ajustes del sodio y alteraciones estructurales en el parénquima renal. Nivel de evidencia Il; Estudios terapéuticos - Investigación de los resultados del tratamiento.

Descriptores: Pruebas de función renal; Suplementos dietéticos; Proteína de suero de leche.

\section{INTRODUCTION}

When carrying out physical exercise, the body reallocates blood to essential areas such as skeletal muscle, reducing the supply in non-essential areas such as the kidney. It is known that the kidney receives about $20 \%$ of the cardiac output in daily activities, and with physical exercise, the kidney becomes very sensitive, thus causing a change in renal physiology'.

Kidney has as one of its physiological functions the elimination of undesirable solutes from the metabolism, including, urea, creatinine, uric acid, hormonal metabolites and blood lysis. This elimination of undesirable products is entirely related to systemic blood flow'.

With intense and prolonged exercise, blood relocation to essential areas causes a state of renal hypoperfusion, with self-regulation of the glomerular filtration rate (GFR). Thus, the kidney is able to maintain normal glomerular filtration and renal plasma flow. Initially, angiotensin II and nitric oxide act by controlling the effects of afferent arterioles vasoconstriction and causing efferent arteriole vasodilation to maintain renal perfusion'.

Whey protein is one of the most widely used supplements, with a high content of amino acid and rich in glutathione precursors, a potent antioxidant ${ }^{2}$. Discovered 3000 years ago, when calves 'stomachs were used to store and transport milk, and through chymosin (rennet), a natural enzyme found in the calves' stomach, came into contact with milk, then coagulated, resulting in two by-products, the curd which is the initial raw material for the production of cheese and milk whey ${ }^{3}$.

According to Maughan and Burke (2004) ${ }^{4}$, the amount of daily protein for an adult is 0.8 to $1.0 \mathrm{~g} /$ day $/ \mathrm{kg}$; for athletes, the amount varies from 1.2 to $1.7 \mathrm{~g} /$ day $/ \mathrm{kg}$. Aparicio et al $(2011)^{5}$ observed that protein dosage above $2.0 \mathrm{~g}$ can be harmful to health. When there is an increase in the concentration of a specific type of amino acid in the plasma and in the glomerular filtrate, the excess that is not reabsorbed will be eliminated in the urine'.

It is widespread in gyms that protein causes muscle hypertrophy, causing damage to health in its excessive use, as described by Sgarbieri $(2004)^{2}$, in which high protein intake can cause risks in the metabolism of liver and kidney functions. Pereira et al $(2003)^{6}$ also reported that the excessive use of protein could cause kidney problems, but this would not be completely elucidated.

Taking into account the high doses of protein ingested by the population adept at physical activity, this protein being converted into ammonia to give rise to urea, where it will be eliminated by the kidney, we can conclude that the excess protein would also lead to an excess of urea $^{7}$, and that excessive protein consumption can affect renal health ${ }^{8,9}$. Thus, what is questioned is whether, in the physical activity of self-performance, the kidney would be weakened due to the decrease in blood flow, leading to glomerular hypoperfusion, thus hindering the excretion of urea, consecutively, leading to a process of kidney injury?

Therefore, the objective of the present study was to evaluate renal function and structure in rats submitted to physical exercise without and with the use of protein supplementation.

\section{MATERIALS AND METHODS}

\section{Experimentation animals and treatment}

Twenty-four male Wistar rats (200 to $250 \mathrm{~g}$ ) were used, a project approved (Protocol No. 003/2016) by the Ethics Committee on Animal Experimentation (CEUA) of FACERES. The animals received a normoproteic diet Labina ${ }^{\oplus}$ (Purina) and water, throughout the study period. The protein used was (PROT) Whey Hydro PRO 2 - Probiótica ${ }^{\circledR}$ being administered orally (gavage), diluted in mineral water $(1.8 \mathrm{~g} / \mathrm{kg}$ of body weight right after swimming training).

The rats were divided into four groups: rats with exercise (Exc), rats without exercise (notExc), rats with exercise and with protein supplementation (Prot/Exc) and rats without exercise and with protein supplementation (Prot/notExc).

\section{Training Protocol}

The animals performed swimming training for 30 minutes daily, using a load equivalent to $2 \%$ of body weight, 5 times a week, for a total of 10 weeks. Protein (Prot) was administered by gavage, once a day, and immediately after training. An asbestos tank (250 litres of water) was maintained at a temperature of $32 \pm 1^{\circ} \mathrm{C}$. After the studies, the animals were destined for the analysis of renal glomerular filtration (FGR), histological analysis and biochemical analyses.

Renal glomerular filtration (FGR) - Creatinine clearance. Urinary volume $(\mathrm{VU})$, fraction of sodium excretion (Fe $\mathrm{Na}$ ) and urinary concentration of urea (Uu).

24 hours after the procedures of each group, the animals were placed in metabolic cages (MA121R, Beira-Mar, Brazil) to collect 24-hour urine to determine the urinary volume $(\mathrm{ml} / \mathrm{min})$ and for biochemical measurements. The rats were submitted to anesthesia with an intraperitoneal injection of $50 \mathrm{mg} / \mathrm{ml} / \mathrm{kg}$ of sodium thiopental. With the animal anesthetized and arterial catheterization (PE 50), blood was collected for biochemical measurements. Were evaluated; plasma and urinary creatinine concentration, urinary urea concentration (Bio-200S,Bioplus,Brazil) and sodium using the electrolyte analyser (Mod. 9180,AVL,USA) (figure 1).

\section{Histological analysis}

The animals were euthanized (anaesthetic overdose) and underwent nephrectomy for histopathological analysis. The kidney was sectioned 


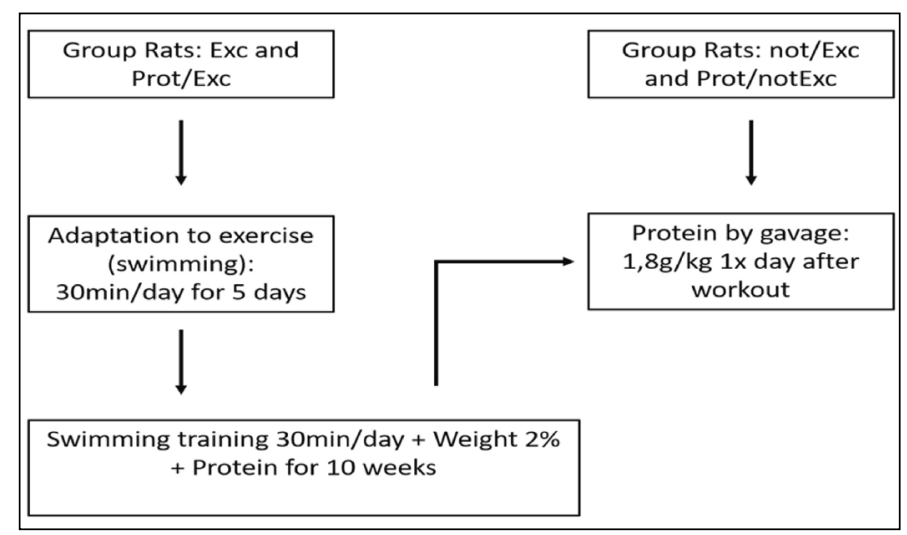

Figure 1. Organization chart of the training protocol.

longitudinally and fixed in $4 \%$ paraformaldehyde in $0.2 \mathrm{M}$ phosphate buffer for 48 hours, and then in $70 \%$ alcohol. The material was processed, and the cuts submitted to HE stains. The analysis was performed in the objective of 40 times, with a score from 0 to 3 for the renal cortical zone. For each score, the percentage of affected fields was assigned, being: 0 : absent hydropic degeneration; 1 : up to $10 \%$ of the affected fields; 2: 11 - $25 \%$ of the affected fields and 3: 26 - 50\% of the affected fields.

\section{Statistical analysis}

The results were previously submitted to descriptive analysis to determine normality. For samples with normal distribution, Analysis of Variance (ANOVA) and Bonferroni test were used. The Kruskal-Wallis test and the Dunn test were used for samples with non-normal distribution. Significance of $5 \%(P \leq 0.05)$.

\section{RESULTS}

\section{FGR}

Values of $1.43 \pm 0.28 \mathrm{ml} / \mathrm{min} / 100 \mathrm{~g}$ in the Exc group, in the notExc group of $1.77 \pm 0.33$; in the Prot/Exc group $2.27 \pm 0.28$ and $2 \pm 0.48$ (Prot/ notExc). Table 1 shows a decrease in FGR for animals in the group Exc vs. Prot/Exc $(p<0.05$; table 1).

\section{Cre $\mathbf{P}$}

Values were similar between the groups that practiced the exercise (Exc $0.69 \pm 0.03 \mathrm{mg} / \mathrm{dl}$ ) vs not practiced (notExc $0.66 \pm 0.04 \mathrm{mg} / \mathrm{dl}$ ). The animals that received supplementation, Prot/Exc $(0.64 \pm 0.12 \mathrm{mg} / \mathrm{dl})$ and without exercise $0.65 \pm 0.11 \mathrm{mg} / \mathrm{dl}$ ( $p>0.05$; Table 1).

\section{Plasma sodium ( $\mathrm{Na} \mathrm{P}$ ) and $\mathrm{Fe} \mathrm{Na}$}

The values were lower when the groups Prot/Exc (119.2 $\pm 6.5 \mathrm{mmol} / \mathrm{L})$ vs Exc $(132.6 \pm 3.8 \mathrm{mmol} / \mathrm{L})$ were compared, $p<0.01$. Similarly, Fe Na was lower when the groups were compared, Prot/Exc $0.54 \pm 0.27 \%$ vs Exc $1 \pm 0.4 \%$ ( $p<0.05$; Table 2$)$.

Table 1. Renal function, urinary volume or urinary flow and weight: comparison between experimental groups.

\begin{tabular}{|c|c|c|c|c|}
\hline \multicolumn{5}{|c|}{ Groups (n) } \\
\hline & Exc & notExc & Prot/Exc & Prot/notExc \\
\hline $\mathrm{FGR}(\mathrm{ml} / \mathrm{min})$ & $1,43 \pm 0,28^{*}(6)$ & $1,77 \pm 0,33(5)$ & $2,27 \pm 0,28(6)$ & $2 \pm 0,48(7)$ \\
\hline CreP (mg/dl) & $0,69 \pm 0,03(6)$ & $0,66 \pm 0,04(6)$ & $0,64 \pm 0,12(6)$ & $0,65 \pm 0,11(7)$ \\
\hline VU (ml/24hs) & $21 \pm 5,8(6)$ & $21 \pm 9,6(5)$ & $18 \pm 4,7(6)$ & $17,7 \pm 4,5(7)$ \\
\hline Peso (g) & $617 \pm 22(6)$ & $627 \pm 65(6)$ & $635 \pm 39(6)$ & $21 \pm 30(7)$ \\
\hline
\end{tabular}

\section{Urea U}

Urea for animals that did not exercise; when the groups were compared, Prot/notExc $33.7 \pm 6.6 \mathrm{mg} / \mathrm{dl}$ vs notExc $54 \pm 5.4 \mathrm{mg} / \mathrm{dl}$, were similar (Table 2)

\section{Histological analysis}

There was a significantly greater hydropic degeneration in the renal tubular cells of animals that did exercise and received supplementation with protein (Figure 2).

Table 2. Fraction of sodium excretion and urea comparison between the experimental groups.

\begin{tabular}{c|c|c|c|c}
\hline \multicolumn{6}{c}{ Groups (n) } \\
\hline & Exc & notExc & Prot/Exc & Prot/notExc \\
\hline $\mathrm{Na} \mathrm{P} \mathrm{(mmol/L)}$ & $1,43 \pm 0,28^{*}(6)$ & $1,77 \pm 0,33(5)$ & $2,27 \pm 0,28(6)$ & $2 \pm 0,48(7)$ \\
\hline $\mathrm{FeNa}(\%)$ & $0,69 \pm 0,03(6)$ & $0,66 \pm 0,04(6)$ & $0,64 \pm 0,12(5)$ & $0,65 \pm 0,11(7)$ \\
\hline $\mathrm{Uu}(\mathrm{mg} / \mathrm{dl})$ & $21 \pm 5,8(6)$ & $21 \pm 9,6(5)$ & $18 \pm 4,7(6)$ & $17,7 \pm 4,5(7)$ \\
\hline
\end{tabular}

The data present mean \pm standard deviation (SD). Exc practiced exercise; notExc did not exercise; Prot/Exc protein supplementation and practiced exercise; Pront/notExc protein supplementation and did not practice exercise. ${ }^{* *} p<0.01$ vs Exc: ${ }^{*} p>0,05$ vs Exc. Plasmatic Sodium ( $\mathrm{Na}$ P), Sodium Excretion Fraction (Fe Na), Urinary Protein (Prot $\mathrm{U})$ and Urinary Urea (Uu)

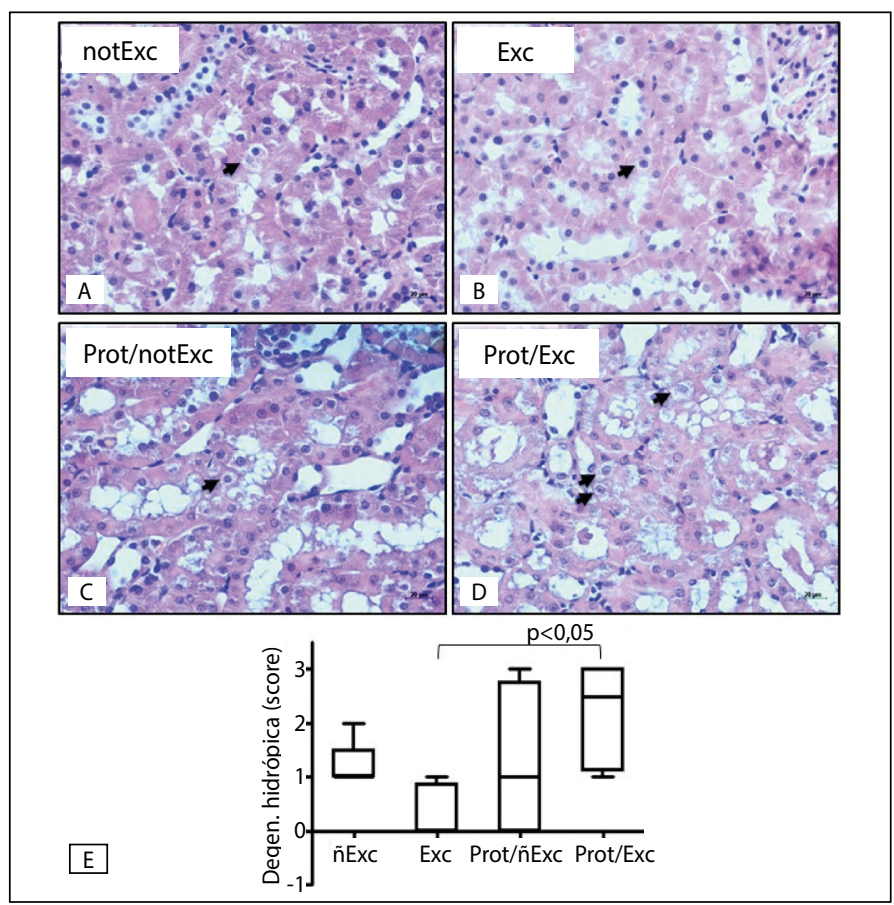

Figure 2. Histopathological analysis. [D-E] Exercise group treated with protein shows an increase in the hydropic degeneration score, compared to the Exercise group (C). Arrows on histological images indicate cells with edematous degeneration [A-D]. Staining: hematoxylin-eosin. 40x objective. $p<0.05$ Prot / Exc versus Exc, Kruskal-Wallis test + Dunn's post-test. Data presented as medians and interquartiles.

\section{DISCUSSION}

According to the Department of Food and Nutrition of the National Research Council/National Academy of Sciences (USA), the recommended daily amount of protein per day is 0.8 grams per kilogram of body weight ${ }^{10}$. There is no benefit in ingesting excess protein, as its excess overloads the liver, responsible for the metabolism of amino acids, and the kidneys, since a large amount of protein metabolism by-products such as urea, ammonia and other nitrogenous products are eliminated through urine. ${ }^{11}$

When the intensity of the exercise exceeds $50 \%$ of the maximum $\mathrm{VO}$, the blood flow to the kidneys, the FGR rate, the sodium excretion and the urinary flow rate decrease by 30 to $60 \%{ }^{12,13,14,15}$. In our results, there was a significant drop in the FGR rate in animals that practiced 
only exercise when compared to animals that practiced exercise and received supplementation. The FGR of animals that practiced only exercise was lower when compared to sedentary ones ( $p>0.05)$. In our experimental conditions, we used an exercise intensity probably corresponding to VO2 max above 50\%, which caused a significant decrease in the FGR of animals that practiced only exercise, and the physiological mechanisms were supplanted by the action of exercise (sympathetic, vasoconstrictor substances, angiotensin). Among the groups that received protein supplementation, animals that practiced exercise vs. sedentary ones, the FGR did not present significant differences ( $p>0.05)$. The vasoconstrictor effect caused by exercise caused a decrease in FGR. We can consider that protein supplementation did not interfere in the FGR rate when administered together with physical activity and also in sedentary rats.

Serum creatinine showed no differences between groups and the values found are among the numbers considered normal for rats ${ }^{16,17,18}$. Renal sodium management is important when using any type of supplementation due to possible actions on renal hemodynamics. Natriuretic effects are counterbalanced by antinatriuretic effects to ensure sodium homeostasis. The excretion of sodium remains normal through tubular readjustments that guarantee your homeostasis without changing your final urinary excretion or the kidney's ability to get rid of saline overloads. In our study, we observed that plasma sodium values are similar to reference values ${ }^{18}$, with the exception of animals that practiced exercise and received protein. The values were significantly lower when compared to animals that performed exercise and without protein $(p<0.01)$.

The pre causes of acute kidney injury can occur due to cardiovascular changes or hypovolemia and liver changes ${ }^{19,20,21}$. The kidneys filter the plasma and do a fine job of fine-tuning the sodium excretion to keep the volume of extracellular fluid constant (sodium excretion below 1\%). The collecting tubule is capable of carrying out this task. In conditions of volume depletion or renal hypoperfusion, the priority becomes sodium conservation and all segments of the nephron will be involved in this effort. These hemodynamic changes may be associated with a drop in the FGR rate, an increase in plasma creatinine and an increase in blood urea concentration. When examining the composition of the urine, the urine flow decreases and the concentration of sodium in the urine becomes very low. In short, the kidney strives to conserve sodium and water. As long as the kidney remains able to concentrate urine and substantially reduce sodium excretion, the pre-renal injury can be reversed by correcting renal hypoperfusion and the primary disorder. Values of the fraction of sodium excretion ( $\mathrm{Fe} \mathrm{Na}$ ) less than $1 \%$ are related to renal hypoperfusion. However, maintaining this hypoperfusion can cause tubular cell damage and necrosis ${ }^{22}$. Excretion of sodium is a good parameter to assess renal insufficiency and failure ${ }^{23}$.

Aparicio et al $(2011)^{5}$ observed that protein dosage above $2.0 \mathrm{~g}$ can be harmful to health. In the experimental model suggested in our study, we used a dose of $1.8 \mathrm{~g} / \mathrm{day} / \mathrm{kg}$, a dose considered for athletes adapted to exercise. The excess protein will undergo a deamination process, where the amino group will be transferred to a-ketoglutaric acid, becoming glutamic acid, releasing ammonia. This will be removed from the blood,

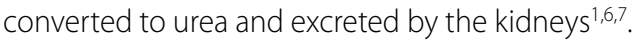

Fe Na values of animals that did not receive protein supplementation remained within the parameters considered normal for rats. The value found in the study by Amaro ${ }^{24}$ was $0.8 \pm 0.05$ and in the work by Catunda ${ }^{25}$ was $0.71 \pm 0.13$, which is close to our results. Fe $\mathrm{Na}$ in animals that received protein supplementation was lower when compared to those that did not receive protein supplementation. It was lower when compared to sedentary animals ( $p>0.05)$ and also when compared to animals that performed the exercise $(p<0.05)$. Urinary sodium was lower for animals that received protein supplementation and performed the exercise, when compared to those that performed only the exercise ( $p>0.05)$. Plasma creatinine and urinary urea did not show significant changes between groups. The VU of the animals that received the protein was lower compared to the animals that did not receive the supplementation ( $p>0.05)$. The $V U$ of the animals that exercised were similar to the reference ${ }^{23}$. Probably the use of protein supplementation at the dose used in our model, and associated with exercise, determined lower Fe $\mathrm{Na}$, with changes in the sodium adjustment tube mechanisms, excreting little sodium, with no significant changes in the plasma creatinine and urea concentration. Cre $P$ showed similarity between the groups, with a significant decrease in the FGR for animals that practiced only exercise in relation to those that practiced exercise and received protein. The vasoconstrictor effect caused by exercise caused changes in renal function and the concomitant use of the protein in the dose proposed by the study, caused changes in the tubular mechanisms of sodium adjustments, excreting little sodium, and without significant changes in the plasma concentration of creatinine and urea.

Histological analysis revealed changes in the renal tubular cells of animals supplemented with protein and exercise, such as the presence of hydropic degeneration (cell edema or vacuolar degeneration). This change was greater for animals that did exercise and receive protein supplementation when compared to animals that just did exercise ( $p<0.05)$. Hydropic degeneration is the first manifestation of almost all forms of cellular damage ${ }^{26}$. The structural changes observed in this study are related to the use of protein supplementation, as evidenced by other authors ${ }^{5,8,9}$

The intracellular accumulation of water demonstrates the cell's inability to maintain ionic balance and fluid homeostasis, and failure in the energy-dependent pumps of these cells' cell membranes. With ionic imbalance, sodium is retained intracellularly, causing the rapid entry of water ${ }^{26}$. As we observed in our results, less sodium excretion in animals that exercised and with protein supplementation. In the microscopic aspect, the cells are enlarged, the nucleus is displaced to the periphery, resulting from the accumulation of water ${ }^{26}$. This change is reversible and dependent on the stimulus, and in the model used in this study, the protein dose determined this degeneration in the renal tubular cells. However, if the supplementation is greater and abusive, this degeneration can progress to irreversible damage and cell death in the renal parenchyma.

\section{CONCLUSIONS}

The practice of physical exercise causes a decrease in the FGR rate, determining changes in renal function. These changes are caused by the intensity of the exercise proposed in the study model. Protein supplementation does not affect the FGR rate.

These results show that exercise in conjunction with protein supplementation determines changes in the tubular mechanisms of sodium adjustment and structural changes in the renal parenchyma.

All authors declare no potential conflict of interest related to this article

AUTHORS' CONTRIBUTIONS: Each author made significant individual contributions to this manuscript. TPA: writing the article, intellectual concept, experiment; CSG: surgery, experiment; MLNG: surgery, writing the article, experiment; CPC: analysis of the slides, revision of the article and statistical analysis; PMC: analysis of the slides and revision of the article; HCC: statistical analysis and administrative support; GEFM: surgery, writing the article, statistical analysis and intellectual concept. 


\section{REFERENCES}

1. Guyton AC, Hall JE. Tratado de Fisiologia Médica. $12^{\circ}$ Edição. Rio de Janeiro: Elsevier; 2011. p. 255-6; 321-40; 1089-99.

2. Sgarbieri VC. Physiological-functional properties of milk whey proteins. Rev Nutr. 2004;17(4):397-409.

3. Smithers GW. Whey and whey proteins - from 'gutter-to-gold'. Dairy J. 2008;18(7):695-704.

4. Maughan RJ, Burke LM. Nutrição Esportiva. Porto Alegre: Artmed; 2004.

5. Aparicio VA, Nebot E, Porres JM, et al. Effects of hight-whey-protein intake and resistance training on renal, bone and metabolic paramenters in rats. Br J Nutr. 2011;105(6):836-45.

6. Pereira RF, Lajolo MF, Hirschbruch MD. Supplement Consumption among fitness center users in São Paulo, Brazil. Rev Nutr. 2003;16(3):265-72.

7. Alves C, Lima RVB. Dietary supplement use by adolescents. J Pediatr. 2009;85(4):287-94

8. Friedman AN. High-protein Diets: Potencial Effects on the Kidney in Renal Health and Disease. Am J Kidney Dis. 2004;44(6):950-62.

9. Jia Y, Hwang SY, House JD, Ogborn MR, Weiler HA, Aukema HM, et al. Long-term high intake of whole proteins results in Renal Damage in Pigs. J Nutr. 2010;140(9):1646-52.

10. Mcardle WD, Katch Fl, Katch VL. Fisiologia do Exercício: Energia, Nutrição e Desempenho Humano. $4^{a}$ ed. São Paulo: Editora Guanabara Koogan; 1998. p. 25.

11. Araújo ACM, Soares YNG. Perfil de utilização de repositores proteicos nas academias de Belém, Pará. Rev Nutr. 1999;12(1):5-19.

12. Zambraski EJ. The kidney and body fluid balance during exercise. In: Burskirk ER, Puhl SM. Body fluid balance: exercise and sport. Boca Raton: CRC; 1996.

13. Tastekin E, Patablyk O, Ulucam E, Uzour S, Karaca A, Vardar AS, et al. The effect of high protein diet and exercise on Irisin, eNOS, and iNOS expressions in kidney. Ren Fail. 2016;38(7):1107-14.

14. Niu YL, Cao JM, Zhou HT, LI J. Effects and mechanisms of 6-week intensive training on renal function in rats. Zhongguo Ying Yong Sheng Li Xue Za Zhi. 2017;34(1):65-8.

15. Zhang Y, Yu XJ, Chen WS, Gao HL, Liu KL, Shi XL, et al. Exercise training attenuates renovasculat hypertension partly via RAS-ROS-glutamate pathway in the hypothalamic paraventricular nucleus. Sci Rep. 2016;24(6):37467.
16. Melo MGD, Dória AA, Serafini AASA, Araújo AAS. Valores de referência hematológicos e bioquímicos de ratos (Rattus novergicus linhagem Wistar) provenientes do Biotério Central da Universidade de Sergipe. Scientia plena. 2011;4(8):1-6.

17. Dantas JA, Ambiel CR, Cuman RKN, Baroni S, Amado CAB. Valores de referência de alguns parâmetros fisiológicos de ratos do Biotério Central da Universidade Estadual de Maringá, estado do Paraná. Acta Sci Health Sci. 2006;28(2):165-70.

18. Branco ACSC, Dias A, Diniz MFFM, Almeida RN, Santos HB, Oliveira KM, et al. Biochemical and hematological parameters of wistar rats and swiss mice the professor Thomas George animal laboratory. Rev Bras Ciências da Saúde. 2011;15(2):209-14.

19. Nunes TF, Brunetta TM, Leal CM, Pisi PCB, Roriz-Filho JS. Insuficiencia renal aguda. Medicina (Ribeirão Preto). 2010;43(3):272-82

20. Abais-Battad JM, Lund H, Fehrencach DJ, Dasinger JH, Mattson DL. Rag1-null Dahl SS rats reveal that adaptative immune mechanisms exacerbate high protein-induced hypertension and renal injury. Am J Physiol Integr Comp Physiol. 2018;315(1):R28-35.

21. Cops J, De Moor B, Haesen S, Lijinem L, Wewns I, Lemoine L, et al. Emdurance exercise intervention is beneficial to kidney function in rat modelo f isolated abdominal venous congestion: a pilot study. J Cardiovasc Transl Res. 2019.

22. Tu L, Burdnann ES, Seguro AC, Helou CMB, Zatz E. Insuficiência (injúria) renal aguda. In: Zatz R. Bases fisiológicas da Nefrologia. São Paulo: Atheneu; 2011. p. 291-313.

23. Borges DR, Birolini D, Atallah AN. Atualização terapêutica de Prado, Ramos e Valle - Diagnóstico e tratamento. 24a Ed. São Paulo: Artes Médicas; 2013.

24. Amaro CRPR, Padovani CR, Gontijo JAR, Figueiredo JF. Avaliação da função tubular proximal utilizando o clearance de lítio no tratamento pela Ciclosporina A em ratos. J Bras Nefrol. 1997;19(4):369-75.

25. Catunda PRR, Deus TF, Ferreira PM, Mendes EP, Pacheco LF. Avaliação de parâmetros renais em ratos submetidos ao treinamento aeróbico moderado e com insuficiência renal aguda induzida por gentamicina. Anais do VIII Seminário de Iniciação Científica e V Jornada de Pesquisa e Pós-Graduação; 10-12 Nov 2010; UEG. Goiás; 2010.

26. Abbas AK, Fausto N, Kumar V. Robbins \& Cotran: Patologia - Bases Patológicas das Doenças. 9a ed. Rio de Janeiro: Guanabara Koogan; 2015. p 45-6; 951-4. 